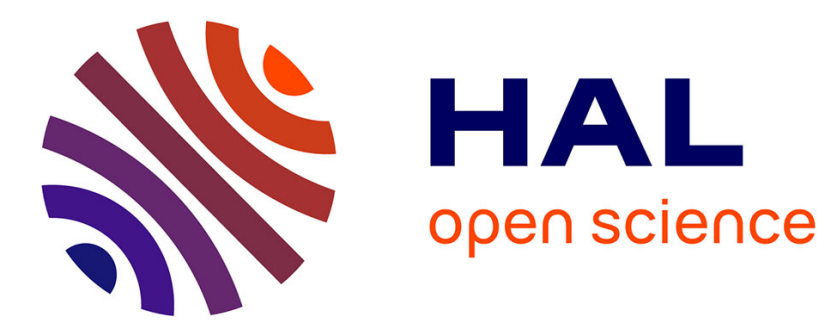

\title{
A high pressure cell for small angle X-ray scattering
}

M. Lorenzen, C. Riekel, A. Eichler, D. Häussermann

\section{To cite this version:}

M. Lorenzen, C. Riekel, A. Eichler, D. Häussermann. A high pressure cell for small angle X-ray scattering. Journal de Physique IV Proceedings, 1993, 03 (C8), pp.C8-487-C8-490. 10.1051/jp4:19938101. jpa-00252231

\section{HAL Id: jpa-00252231 https://hal.science/jpa-00252231}

Submitted on 1 Jan 1993

HAL is a multi-disciplinary open access archive for the deposit and dissemination of scientific research documents, whether they are published or not. The documents may come from teaching and research institutions in France or abroad, or from public or private research centers.
L'archive ouverte pluridisciplinaire HAL, est destinée au dépôt et à la diffusion de documents scientifiques de niveau recherche, publiés ou non, émanant des établissements d'enseignement et de recherche français ou étrangers, des laboratoires publics ou privés. 


\title{
A high pressure cell for small angle X-ray scattering
}

\author{
M. LORENZEN, C. RIEKEL, A. EICHLER ${ }^{*}$ and D. HÄUSSERMANN \\ ESRF, BP. 220, 38043 Grenoble cedex, France \\ * Institut für Technische Physik, Mendelssohnstr. 2, 38106 Braunschweig, Germany
}

The construction of a high-pressure cell for small-angle $X$-ray scattering experiments is described. The cell will operate up to $10 \mathrm{kbar}$ and $300^{\circ} \mathrm{C}$. It has been conceived to be used on SAXS-cameras at the European Synchrotron Radiation Facility.

\section{Introduction}

Phase transformations in synthetic polymers have been widely studied by small-angle (SAXS) and wideangle X-ray scattering (WAXS). In particular thermally driven phase transitions have been studied in detail at synchrotron-radiation sources [1]. The behavior of solid polymers under high pressure is, however, largely unexplored. Today the best studied case is polyethylene (PE) which has been examinated in-situ by WAXS [2,3], optical [4] and calorimetric measurements [5]. No in-situ SAXSexperiments on solid polymers under high pressure have been reported.

The present article will report on the technical realization of a pressure cell for SAXS-experiments which will allow to study high pressure phase transformations under static and dynamic conditions. The operating range of $\leq 10 \mathrm{kbar}$ and $\leq 300^{\circ} \mathrm{C}$ has been chosen in view of the phase diagram of $\mathrm{PE}$.

\section{Instrumental Requirements}

There are several instrumental requirements for high pressure SAXS experiments on polymers and especially on PE:

- Ultrahigh SAXS-resolution is necessary as ex-situ SAXS and electron microscopy on PE indicate the development of morphological features up to several $1000 \AA[6]$.

- A shorter wavelength than the usually used $1.5 \AA$ [1] at SR-sources is required in order to reduce absorption by the windows and pressure transmitting medium.

SAXS-experiments down to $\lambda=0.2 \AA$ have been reported [7]. The Bonse-Hart optics chosen for these experiments produced, however, a line-focus which limits the flux for small-windows of highpressure cells. A double focusing pin-hole optics is better suited for high-pressure applications but the use of such optics at very small wavelength is unexplored for in-situ experiments due to the 
difficulty in focusing and the loss in flux at short wavelength. It therefore appears to be reasonable to limit the wavelength to $\approx \mathrm{MoK} \alpha$ which can still be handled by classical mirror optics.

The focal spot should be as small as possible in order to be able to reduce the window thickness and hence absorption.

The ESRF high-brilliance SAXS camera [8] is of particular interest for high-pressure experiments because it can be used down to $0.7 \AA$. It has a spot size at the sample position of $<1 \mathrm{~mm}^{2}$ and can reach ultralow Q-values due to the small divergence of undulator radiation sources. Prior to the availability of this beamline ( $\geq 1994$ ) it will be possible to use the SAXS-beamline on the ESRF microfocus beamline which, however, is limited to $\lambda \approx 1 \AA$ at present [9].

\section{High Pressure Cell}

Figures 1 and 2 show a schematical drawing of the cell and a detailed layout. The choice of this geometry is due to several physical and technical requirements. Thus the cell has to withstand sufficiently high temperatures and pressures. Since PE has a phase transition at around $3.3 \mathrm{kbar}$ and PTFE around $5 \mathrm{kbar}$ [10] the pressure range is chosen up to $10 \mathrm{kbar}$. Furthermore a temperature range up to $300^{\circ} \mathrm{C}$ is required. Both ranges can be extended to higher values if necessary.

The cell itself is a piston cylinder cell with a perpendicular bore for the X-ray windows. It is made out of hardened maraging steel. The necessary thickness of the cell wall can be calculated from the relationships

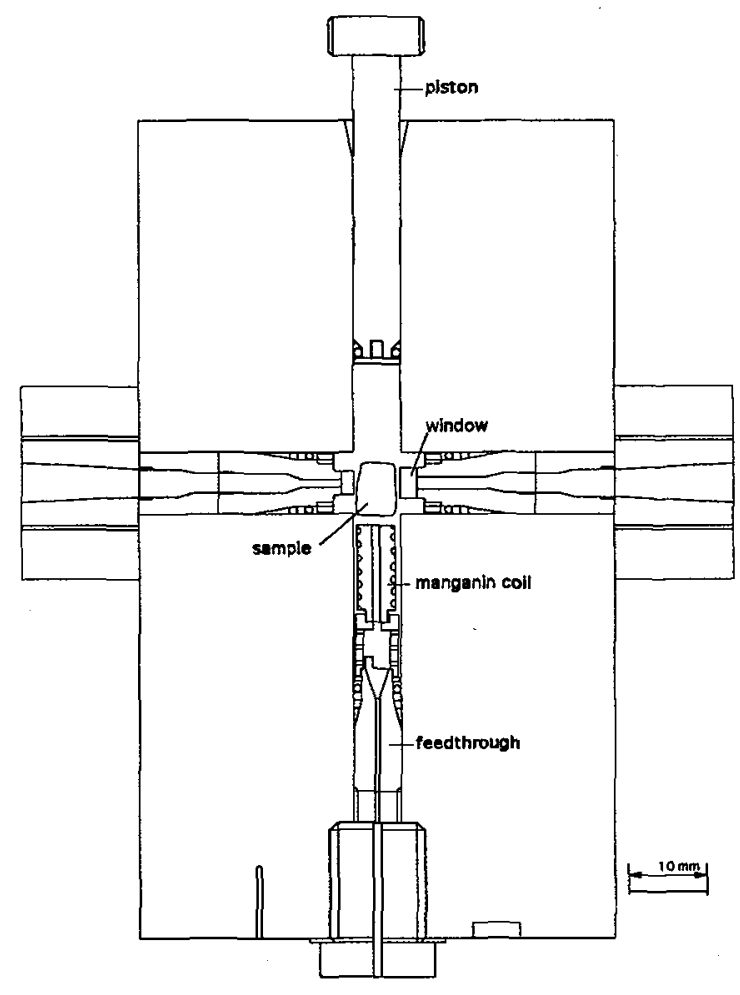

Figure 1. Schematic view on high pressure cell

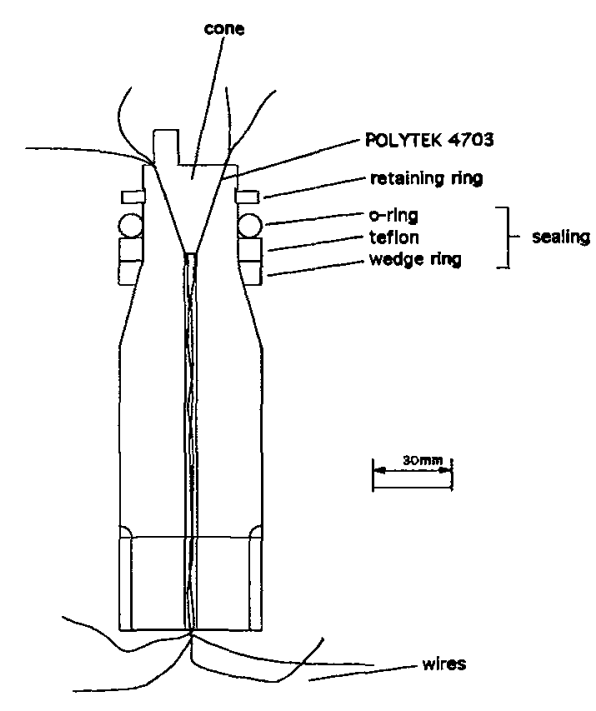

Figure 2. Detailed view on feedthrough and sealing principle 
for stress and strain [11]. For the present design the results show that the outer radius has to be chosen 5 times bigger than the inner one, and must be doubled once more because of the perpendicular bore. This demonstrates the necessivity to keep the inner bore small to reduce the mass and thus save heating power or- even more important- shorten heating periods.

A small size of the cell is also favourable because of the absorption (see above) but is limited by the space which is necessary for the feedthrough so that the chosen bore size is a compromise.

In order to ensure hydrostatic pressure on the sample a liquid as pressure transmitting medium was chosen. Silicon oil is a widely used pressure liquid in polymer science and no reactions with the samples were found .

Pressure is produced by a hydraulic oil pump and a mechanical amplifier which drives a piston into the cell. The pressure is measured inside the cell via the resistance of a manganin coil (see figure 1). It is also possible to measure the pressure with a Heise gauge at the hydraulic press and to calculate the inside pressure. However, due to the the friction of the piston in the bore this method leads to errors dependent on the direction of piston movement.

External heating by a wire coiled around the cell was chosen because of the lack of space inside the cell. Calculations for the chosen cell geometry show that the temperature difference between the interior of the cell and the outside - which depends on the heating rate- must not exceed $10^{\circ} \mathrm{C}$, otherwise the resulting stress can lead to the burst of the cell. This limits the heating rate to $\approx 2{ }^{\circ} \mathrm{C} / \mathrm{min}$ maximum. The temperature difference necessarily calls for a measurement of the temperature inside the cell near the sample. A thermocouple type $\mathrm{K}$ is used for this purpose. This requires a feedthrough of the wires from ambient pressure to high pressure inside the cell. Several solutions have been reported in literature ( see Ref.11 for an overview ). A construction which is simple as well as easily and quickly prepared has been looked for. An additional complication, however, is the need for high temperatures in the present case.

The final solution for the feedthrough is shown in detail in Fig. 2. In consists of a $36^{\circ}$ cone and hole between which the wires pass. The sealing is ensured by a high temperature varnish (POLYTEK 4703). As window material diamond is used because of its strength which allows to use thin windows. Table I shows the contribution of the different materials of the high pressure cell to the absorption at $0.7 \AA$. The overall transmission of all materials in the beam is $36 \%$.

SAXS measurements were performed at the JUSIFA beamline at Hasylab [12] on the geometrie of the high pressure cell in order to verify the scattering properties of the cell. It was found that the underground produced by the diamonds and the silicon oil is several orders of magnitude lower than the scattering from PE.

Table I Transmission at $0.7 \AA$ of several materials of the high pressure cell

$$
\text { thickness transmission }
$$

$\begin{array}{lll}\text { PE } & 4 \mathrm{~mm} & 81 \% \\ \text { Silicon oil } & 2 \mathrm{~mm} & 86 \% \\ \text { Diamond } & 3.5 \mathrm{~mm} & 51 \%\end{array}$




\section{Acknowledgement}

We wish to thank Dr. D. Häusermann for his support in the design of the high-pressure cell. Thanks are due to Prof. Dr. W. F. Sherman who made his amplification system available to us. Günther Goerigke helped during the Hasylab experiments.

\section{References}

[1] Elsner G., Riekel C., Zachmann H. G. in: Advances in Polymer Science 67; Ed.: H. H. Kausch and H. G. Zachmann, Springer: Berlin, 1985

[2] Basset D. C., Block S., Piermarini G. J., J. of Appl. Phys. 45 (1974) 4146

[3] Yasuniwa M., Enoshita R., Takemura T., Jap. J. of Appl. Phys. 15 (1976) 1421

[4] Hikosaka M., Seto T., Jap. J. of Appl. Phys. 21 (1982) L332

[5] Rastogi S., Hikosaka M., Kawabata H., Keller A., Macromolecules 24 (1991) 6384

[6] Bassett D. C., Carder, D. R.; Polymer 14 (1973) 387

[7] Siddons, P.; Riekel C., Hastings J., J. Appl. Cryst. 23 (1990) 401

[8] Riekel C., Bösecke P., Rio M. S. d., Rev. Sci. Instr. 63 (1992) 974

[9] Riekel C. et al to be published

[10] Goldman A. Y., Khanarin V. S., Sysoyev I. V., Pol. Sci. U.S.S.R. 31 (1989) 751

[11] Sherman W. F., Stadtmuller A. A., Experimental Techniques in High-Pressure Research 1987, J. Willis \& Sons Ltd.

[12] Haubold H., Gruenhagen K., Wagener M., Jungbluth H., Heer H., Pfeil A., Brandenberg G., Moeller R., Matzerath J., Hiller P., Halling H., Rev. Sci. Instrum. 60 (1989) 1943 